\title{
ANALISIS IMPLEMENTASI NILAI PERUSAHAAN PADA PERUSAHAAN SEKTOR CONSUMER GOODS
}

\author{
Ni Luh Tiya Arini ${ }^{1}$ \\ Ni Nyoman Ayu Suryandari ${ }^{2}$ \\ A.A. Putu Gde Bagus Arie Susandya ${ }^{3}$ \\ Universitas Mahasaraswati Denpasar 1, 2,3 \\ email: tiyaarini12@gmail.com
}

\begin{abstract}
Company value is the company's performance which is reflected by the price of shares formed by the demand and supply of capital markets that reflect the public's assessment of the company's performance. Increasing company value is a long-term goal that the company should have achieved that will be reflected in the stock market price. This study aims to determine the effect of corporate social responsibility, intellectual capital, dividend policy and the ratio of solvency to firm value. The sample in this study were 18 consumer goods sector companies listed on the Indonesia Stock Exchange for the 2016-2018 period. Determination of the sample using purposive sampling technique. The analytical tool used is multiple linear regression analysis. The results showed that the variable corporate social responsibility did not affect the value of the company, intellectual capital variables, dividend policy and solvency ratios had a positive effect on firm value.
\end{abstract}

Keywords: corporate value, corporate social responsibility, intellectual capital, dividend policy, solvency ratio.

\section{PENDAHULUAN}

Tujuan utama perusahaan yang telah go public adalah memaksimalkan nilai perusahaan melalui peningkatan kemakmuran para stakeholdernya (Nurfina, 2016). Peningkatan nilai perusahaan merupakan tujuan jangka panjang yang seharusnya dicapai perusahaan yang akan tercermin dari harga pasar sahamnya karena penilaian investor terhadap perusahaan dapat diamati melalui pergerakan harga saham perusahaan.

Nilai perusahaan merupakan kinerja perusahaan yang dicerminkan oleh harga saham yang dibentuk oleh permintaan dan penawaran pasar modal yang merefleksikan penilaian masyarakat terhadap kinerja perusahaan (Harmono, 2014). Oleh karena itu, nilai perusahaan sangatlah penting karena dapat mempengaruhi persepsi investor terhadap perusahaan. Corporate Social Responsibilty (CSR) atau tanggung jawab sosial perusahaan merupakan suatu pertanggungjawaban yang diberikan oleh perusahaan untuk memenuhi keutuhan para stakeholder baik internal maupun eksternal. Corporate Social Responsibility dimaksudkan supaya perusahaan bisa lebih etis dalam menjalankan kegiatan usahannya agar tidak berdampak 
buruk pada lingkungan sekitar atau masyarakat (Khafa, 2015).

\section{Penerapan Corporate Social} Responsibility dapat menurunkan biaya operasi suatu perusahaan. Hal tersebut dikarenakan setelah diterapkannya $C S R$, perusahaan akan mengurangi biaya yang dikeluarkan untuk pemasaran produk dan menggantinya dengan biaya $C S R$.

Semakin banyak bentuk pertanggungjawaban yang dilakukan perusahaan terhadap lingkungannya, citra perusahaan menjadi lebih baik. Investor lebih berminat pada perusahaan yang memiliki citra yang baik di masyarakat karena semakin baik citra perusahaan, loyalitas konsumen semakin meningkat. Berdasarkan penelitian Setyowati (2014) dan Jitmaneeroj (2017) menyatakan bahwa Corporate Social Responsibility berpengaruh positif terhadap nilai perusahaan. Sedangkan berdasarkan hasil penelitian Nurfina (2016) menyatakan bahwa Corporate Social Responsibility tidak berpengaruh terhadap nilai perusahaan.

Intellectual capital merupakan sumber daya berupa pengetahuan dalam bentuk karyawan, pelanggan, proses atau teknologi yang tersedia pada perusahaan yang menghasilkan aset bernilai tinggi dan manfaat ekonomi di masa mendatang bagi perusahaan (Fauzia , 2016).

Kemajuan teknologi dan
menyebabkan
$\begin{aligned} & \text { informasi } \\ & \text { perkembangan ekonomi saat ini } \\ & \text { dikendalikan oleh informasi dan }\end{aligned}$

pengetahuan, hal ini membawa sebuah peningkatan perhatian pada modal intellektual (Rofik, 2017). Semakin besar VAIC semakin efisien penggunaan IC perusahaaan yang dapat menciptakan nilai tambah bagi perusahaan. Penelitian yang dilakukan oleh Nuryaman (2015) menyatakan bahwa intellectual capital berpengaruh positif terhadap nilai perusahaan dan penelitian Ahmed (2016) menyatakan bahwa intellectual capital berpengaruh positif dan signifikan terhadap nilai perusahaan. Sedangkan, hasil penelitian Rofik (2017) menunjukkan bahwa intellectual capital tidak berpengaruh terhadap nilai perusahaan.

Kebijakan dividen adalah penentuan tentang berapa besarnya laba yang diperoleh dalam suatu periode akan dibagikan kepada pemegang saham dalam bentuk dividen, dan akan ditahan perusahaan dalam bentuk laba ditahan (Halim, 2015). Kebijakan deviden yang menguntungkan bagi investor, tentu akan membuat investor tertarik untuk menanamkan modalnya pada perusahaan yang selanjutnya akan meningkatkan nilai perusahaan. Berdasarkan penelitian Arifah (2015) dan Azis (2017) menyatakan bahwa kebijakan deviden berpengaruh positif terhadap nilai perusahaan. Sedangkan penelitian Endarmawan (2014) menyatakan bahwa kebijakan deviden tidak berpengaruh terhadap nilai perusahaan.

Rasio solvabilitas merupakan rasio yang digunakan untuk mengukur 
sejauh mana aktiva perusahaan dibiayai dengan hutang. Peningkatan rasio DER akan dinilai kurang bagus oleh investor, karena semakin tinggi rasio DER maka semakin rendah kemampuan perusahaan untuk membayarkan dividen payout ratio kepada pemegang saham, sehingga rasio pembayaran dividen semakin rendah. Hal ini akan menyebabkan para investor berpikir dua kali untuk menanamkan modalnya pada perusahaan tersebut, sehingga akan berdampak pada menurunnya nilai perusahaan. Berdasarkan penelitian Lutfiana (2018) menyatakan bahwa solvabilitas berpengaruh positif dan signifikan terhadap nilai perusahaan dan berdasarkan penelitian Noviyani (2018) menyatakan bahwa solvabilitas berpengaruh positif terhadap nilai perusahaan. Sedangkan, berdasarkan penelitian Hapsak (2018) menyatakan bahwa solvabilitas berpengaruh negatif terhadap nilai perusahaan.

Penelitian ini menggunakan populasi pada perusahaan sektor consumer goods yang terdaftar di Bursa Efek Indonesia periode tahun 2016-2018. Perusahaan consumer goods merupakan salah satu sektor perusahaan yang memiliki prospek yang bagus dan juga tahan terhadap krisis. Produk dari perusahaan sektor consumer goods tersebut merupakan kebutuhan sehari- hari yang diperlukan oleh masyarakat banyak. Diharapkan penjualan dan profit yang diterima oleh perusahaan akan meningkat atau stabil, sehingga investor lebih tertarik untuk berinvestasi di sektor tersebut

\section{TINJAUAN PUSTAKA}

Teori Signal (Signalling Theory)

Signaling theory merupakan suatu perilaku manajemen perusahaan dalam memberi petunjuk untuk investor terkait pandangan manajemen pada prospek perusahaan untuk masa yang akan datang (Bringham dan Houston, 2014). Signaling theory memberikan dorongan kepada perusahaan untuk memberikan informasi kepada pihak eksternal. Dorongan tersebut timbul akibat dari asimetri informasi antara pihak manajemen terhadap pihak eksternal.

\section{Legitimacy theory}

Legitimacy

theory

mengungkapkan bahwa perusahaan secara kontinyu berusaha untuk bertindak sesuai dengan batas-batas dan norma-norma dalam masyarakat, atas usahanya tersebut perusahaan berusaha agar aktivitasnya diterima menurut persepsi pihak eksternal (Khafa, 2015). Legitimasi didapatkan jika apa yang dijalankan oleh perusahaan telah selaras dengan apa yang juga diinginkan oleh masyarakat.

\section{Stakeholder Theory}

Manajemen

organisasi diharapkan untuk melakukan aktivitas yang dianggap penting bagi stakeholder mereka dan melaporkan kembali aktivitas-aktivitas tersebut pada stakeholder. Tujuan dari teori stakeholder adalah untuk membantu manajer korporasi dalam meningkatkan nilai sebagai akibat dari aktivitas-aktivitas yang dilakukan dan meminimalkan kerugian bagi stakeholder (Fauzia, 2016). Tujuan utama dari teori stakeholder adalah untuk membantu manajer korporasi mengerti lingkungan stakeholder mereka dan melakukan pengelolaan 
Journal of Applied Management and Accounting Science (JAMAS)

(Ni Luh Tiya Arini, Ni Nyoman Ayu Suryandari, A.A. Putu Gde Bagus Arie Susandya, 38 - 55) Vol 1, No 1, Desember 2019

dengan lebih efektif dilingkungan perusahaan mereka.

\section{Hipotesis}

$\begin{array}{lcr}\text { Pengaruh } & \text { Corporate } & \text { Social } \\ \text { Responsibility } & \text { Terhadap } & \text { Nilai } \\ \text { Perusahaan } & & \end{array}$

Investor sangat menghargai praktik CSR didalam perusahaan dan mengetahui bahwa aktivitas CSR sebagai informasi untuk menilai keberlangsungan hidup suatu perusahaan dimasa yang akan datang. Apabila suatu perusahaan melakukan pengungkapan tanggung jawab sosial secara berkesinambungan maka citra perusahaan di pihak eksternal perusahaan akan semakin baik. Hal ini akan berpengaruh terhadap semakin tingginya loyalitas konsumen kepada perusahaan (Hartoyo, 2016). Investor akan dapat memberikan apresiasi positif dengan berinvestasi pada perusahaan tersebut kemudian harga saham perusahaan akan naik dan menyebabkan meningkatnya nilai perusahaan. Penelitian Setyowati (2014) dan Jitmaneeroj (2017) menyimpulkan bahwa corporate social responsibility berpengaruh positif terhadap nilai perusahaan.

$\mathrm{H}_{1}$ : Corporate Social Responsibility berpengaruh positif terhadap nilai perusahaan.

\section{Pengaruh Intellectual Capital Terhadap Nilai Perusahaan}

Usaha yang dilakukan oleh suatu perusahaan dalam menciptakan sebuah nilai perlu adanya suatu pemanfaatan sumber daya yang dimiliki oleh suatu perusahaan. Potensi tersebut terdiri dari human capital, customer capital, dan structural capital. Nilai tambah yang dihasilkan dari proses penciptaan

$$
\begin{aligned}
& \text { sebuah nilai dalam perusahaan } \\
& \text { tersebut akan menciptakan } \\
& \text { keunggulan kompetitif bagi } \\
& \text { perusahaan. Para investor akan } \\
& \text { menunjukkan apresiasi atas } \\
& \text { keunggulan IC yang dimiliki }
\end{aligned}
$$
$\mathrm{H}_{2}$ : Intellectual capital berpengaruh positif terhadap nilai perusahaan.

\section{Pengaruh Kebijakan Dividen Terhadap Nilai Perusahaan \\ Pembagian dividen} menunjukkan kinerja perusahaan yang meningkat, dividen juga digunakan untuk meningkatkan kemakmuran dari pemegang saham.

Pembagian dividen yang semakin besar maka akan menarik minat investor untuk menanamkan modalnya sehingga dapat meningkatkan harga pasar saham kemudian akan berdampak pada nilai perusahaan yang semakin tinggi, hal ini dikarenakan para investor lebih menyukai dividend yield dibandingkan dengan capital gains (Arindita, 2015). Penelitian Arifah (2015) dan Azis (2017) menyimpulkan bahwa kebijakan deviden berpengaruh positif terhadap nilai perusahaan. Berdasarkan penjelasan diatas dapat disusun hipotesis sebagai berikut :

$\begin{array}{rlr}\mathrm{H}_{3}: & \begin{array}{l}\text { Kebijakan deviden } \\ \text { berpengaruh positif terhadap } \\ \text { nilai perusahaan. }\end{array}\end{array}$




\section{Pengaruh Rasio Solvabilitas Terhadap Nilai Perusahaan}

Penggunaan utang dalam kegiatan operasional perusahaan yang melebihi penggunaan modal sendiri dapat meningkatkan peluang kebangkrutan. Hal ini disebut sebagai cost of financial distress, merupakan kondisi dimana perusahaan mengalami kesulitan keuangan dan terancam bangkrut (Arindita, 2015).

Investor pun mengasumsikan perusahaan yang mempunyai hutang yang besar, maka akan terdapat risiko yang besar sehingga investor memilih untuk tidak berinvestasi pada perusahaan tersebut. Hal ini akan berpengaruh pada menurunnya nilai perusahaan. Penelitian yang dilakukan oleh Hapsak (2018) menyatakan bahwa terdapat hubungan negatif antara rasio solvabilitas dengan nilai perusahaan. Sehingga dapat disusun hipotesis mengenai struktur modal terhadap nilai perusahaan yaitu sebagai berikut:

$\mathrm{H}_{4}$ : Rasio Solvabilitas berpengaruh negatif terhadap nilai perusahaan.

\section{METODE PENELITIAN}

\section{Lokasi Penelitian}

Penelitian ini dilakukan pada Bursa Efek Indonesia (BEI) dengan mengakses situs resmi Bursa Efek Indonesia (BEI) yaitu www.idx.co.id.

\section{Identifikasi Variabel}

Variabel-variabel

yang

digunakan dalam penelitian ini adalah:

1) Variabel dependen (Y) merupakan variabel yang dipengaruhi atau menjadi akibat karena adanya variabel bebas (Sugiyono, 2013). Variabel dependen dalam penelitian ini adalah nilai perusahaan. $\begin{array}{lcr}\text { 2) } & \text { ariabel } & \text { independen } \\ \text { merupakan } & \text { variabel } & \text { yang }\end{array}$ mempengaruhi atau menjadi sebab perubahan atau timbulnya variabel dependen (Sugiyono 2013). Variabel independen dalam penelitian ini adalah, Corporate Social Responsibility (CSR), Intellectual Capital (IC), Kebijakan Dividen (Div) dan Rasio Solvabilitas (Solv).

\section{Definisi Operasional Variabel}

1) Corporate Social Responsibility (CSR)

Pengukuran pengungkapan corporate social responsibility pada penelitian ini konsisten dengan penelitian yang dilakukan Setianingrum (2015) yaitu diukur dengan menggunakan indikator dari Global Reporting Initiative (GRI) G.3. Indeks Global Reporting Initiative (GRI) G.3 terdiri dari 79 indikator, terdiri dari 9 indikator ekonomi, 30 indikator lingkungan, 14 indikator tenaga kerja, 9 indikator HAM, 8 indikator sosial dan 9 indikator produk. Pengukuran Indeks CSR dilakukan dengan rumus sebagai berikut:

$$
\operatorname{CSR}=\frac{\sum \mathbf{X} \mathbf{i}}{\mathbf{n i}}
$$

\section{2) Intellectual Capital}

Pengukuran IC secara tidak langsung dengan menggunakan Value Added Intellectual Coefficient (VAIC). VAIC adalah suatu ukuran untuk menilai efisiensi dari nilai tambah sebagai hasil dari kemampuan intellectual perusahaan (Hadiwijaya, 2013).

Tahapan perhitungan modal intelektual menggunakan model VAIC adalah sebagai berikut:

a) Menghitung Value Added (VA). 
VA dihitung sebagai selisih antara output dan input (Aprianti, 2018). Formulasinya sebagai berikut :

$\mathrm{VA}=$ OUTPUT - INPUT

Dimana :

Output : Total Pendapatan

Input : Total Beban (selain beban karyawan).

b) Tahap kedua yaitu dengan menghitung $V A C E$ yang merupakan perbandingan Value Added (VA) dengan Capital Employed (CE).

Formulasinya sebagai berikut:

Dimana :

$\mathrm{VACE}=\mathrm{VA} / \mathrm{CE}$

VA : Value Added

CE: Capital Employed : dana yang tersedia (total ekuitas)

c) Tahap ketiga yaitu dengan menghitung Value Added Human Capital (VAHU). VAHU adalah perbandingan antara Value Added (VA) dengan Human Capital (HC). Formulasinya sebagai berikut:

$V A H U=\mathrm{VA} / \mathrm{HC}$

Dimana :

VA : Value Added

HC (Human Capital) : Beban tenaga kerja/ karyawan

d) Tahap keempat yaitu menghitung STVA yang merupakan rasio $S C$ terhadap $V A$. Formulasinya sebagai berikut:

STVA $=$ SC/VA

Dimana :

VA : Value Added

SC (Structural Capital): VA - HC

e) Tahap kelima yaitu menghitung Value Added Intellectual Coefficient (VAIC).

VAIC merupakan penjumlahan dari 3 komponen sebelumnya yaitu : VACE, VAHU, dan STVA. Formulasinya sebagai berikut: $\mathrm{VAIC}=\mathrm{VACE}+\mathrm{VAHU}+\mathrm{STVA}$

\section{3) Kebijakan Dividen}

Kebijakan dividen diukur menggunakan Dividend Payout Ratio $(D P R)$.Formulasinya adalah sebagai berikut (Arindita, 2015) :

$$
\mathrm{DPR}=\frac{\text { Dividen } \text { per share }}{\text { Earning per share }}
$$

\section{4) Rasio Solvabilitas}

Pengukuran rasio solvabilitas dalam penelitian ini menggunakan proksi Debt to Equity Ratio.

Formulasinya sebagai berikut (Sartono, 2014) :

DER $=\frac{\text { Total Liabilitas }}{\text { Total Ekuitas }} \times 100 \%$

\section{5) Nilai perusahaan}

Pengukuran nilai perusahaan dalam penelitian ini menggunakan proksi Price to Book Value (PBV). Formulasinya sebagai berikut (Hadiwijaya, 2013) :

$\mathrm{PBV}=\frac{\text { Harga saham }}{\text { Nilai buku per saham }}$

\section{Metode Penentuan Sampel}

Kriteria pemilihan sampel perusahaan sektor consumer goods yang tercatat di Bursa Efek Indonesia periode 2016-2018 berdasarkan purposive sampling adalah:

1. Perusahaan sektor consumer goods yang terdaftar di Bursa Efek Indonesia pada periode tahun 20162018.

2. Perusahaan tidak mengalami delisting dari Bursa Efek Indonesia selama periode tahun 2016-2018.

3. Perusahaan sektor consumer goods yang mempublikasikan laporan tahunan periode tahun 2016-2018 secara lengkap.

4. Perusahaan yang membagikan deviden selama periode tahun 20162018 . 


\section{Tabel 4.1}

Penentuan Sampel Penelitian

\begin{tabular}{|c|c|c|}
\hline No & Kriteria & $\begin{array}{c}\text { Jumlah } \\
\text { Perusahaan }\end{array}$ \\
\hline 1. & $\begin{array}{c}\text { Perusahaan consumer goods yang terdaftar } \\
\text { di BEI periode tahun 2016-2018 }\end{array}$ & 51 \\
\hline 2. & $\begin{array}{c}\text { Perusahaan yang mengalami delisting } \\
\text { selama periode tahun 2016-2018 }\end{array}$ & $(1)$ \\
\hline 3. & $\begin{array}{c}\text { Perusahaan yang tidak mempublikasikan } \\
\text { laporan tahunannya secara lengkap }\end{array}$ & $(14)$ \\
\hline 4. & $\begin{array}{c}\text { Perusahaan yang tidak membagi deviden } \\
\text { selama periode tahun 2016-2018 }\end{array}$ & $(18)$ \\
\hline & Jumlah Sampel & 18 X 3 = 54 \\
\hline
\end{tabular}

\section{Sumber: Data diolah (2019)}

\section{Teknik Analisis Data}

Analisis data digunakan untuk memperkirakan besarnya pengaruh secara kuantitatif dari perubahan suatu atau beberapa kejadian terhadap suatu atau beberapa kejadian lainnya. Analisis kuantitatif yaitu analisis yang digunakan terhadap data yang berwujud angka-angka atau data kualitatif yang diangkakan. (Sugiyono, 2013).

\section{Teknik Analisis Data \\ Analisis Statistik Deskriptif}

Menurut Ghozali (2016), Statistik Deskriptif bertujuan untuk memberikan gambaran mengenai suatu data yang dilihat dari rata-rata (mean), standar deviasi, varian, maksimum dan minimum.

\section{Analisis Regresi Berganda}

Analisis regresi adalah analisis yang mengukur kekuatan hubungan antar dua variabel atau lebih dan menunjukkan arah hubungan antara variabel dependen dengan variabel independen (Ghozali, 2016).

Berikut adalah model analisis regresi berganda.

Rumus: Value $=\alpha+\beta_{1}$ CSR $+\beta_{2} I C$ $+\beta_{3} \operatorname{Div}+\beta_{4} \operatorname{Solv}+\mathrm{e}$
Keterangan :

Value $=$ Nilai Perusahaan

CSR = Corporate Social

Responsibility

IC =Intellectual Capital

Div = Kebijakan dividen

Solv = Rasio Solvabilitas

$\alpha \quad=$ Konstanta

$\beta_{1}, \ldots \ldots, \ldots \beta_{4}=$ Koefisien regresi

$\mathrm{e} \quad=$ error term atau derajat kesalahan.

\section{Uji Asumsi Klasik}

1) Uji Normalitas

Uji normalitas bertujuan untuk menguji dalam model regresi antara variabel dependen dengan variabel independen apakah memiliki distribusi normal atau tidak. Model regresi yang baik adalah yang memiliki distribusi data normal atau mendekati normal.

2) Uji Multikolinearitas

Model regresi yang baik seharusnya tidak terjadi korelasi diantara variabel independen (Ghozali, 2016). Pengujian multikolinieritas dapat dilihat dari nilai tolerance dan nilai Variance Inflation Factor (VIF). Suatu model regresi dikatakan bebas dari multikolinearitas jika memiliki nilai 
tolerance $>0,1$ atau mendekati 1 dan memiliki nilai $\mathrm{VIF}<10$.

3) Uji Autokorelasi

Pengujian autokorelasi dengan menggunakan uji Durbin-Watson, yaitu dengan menghitung nilai $d$ statistik dengan tingkat signifikansi 0,05 . Model regresi bebas dengan autokorelasi apabila nilai koefisien Durbin-Watson terletak antara du dan 4-du.

4) Uji Heteroskedastisitas

Pengujian ini dilakukan dengan merespon variabel independen dengan nilai absolut unstandardized residual regresi sebagai variabel dependen. Apabila hasil uji signifikan lebih besar dari 0,05 maka tidak terdapat heterokestisitas, dan apabila nilai signifikansi di bawah 0,05 maka terdapat gejala heterokestisitas.

\section{Pengujian Hipotesis}

Pengujian hipotesis dilakukan dengan 3 uji yaitu uji Koefisien Determinasi $\left(\mathrm{R}^{2}\right)$, uji $\mathrm{F}$, dan uji t.

1) Uji Koefisien Determinasi $\left(\mathrm{R}^{2}\right)$

Nilai koefisien determinasi adjusted $\mathrm{R}^{2}$ adalah antara nol dan satu (Ghozali, 2016). Jika variabel uji adjusted $\mathrm{R}^{2}$ memiliki nilai 0 atau mendekati 0 berarti kemampuan variabel independen dalam menjelaskan variabel dependen mengalami keterbatasan, tetapi jika variabel uji $\mathrm{R}^{2}$ bernilai 1 atau mendekati 1 maka variabel independen memberikan hampir semua informasi yang dibutuhkan untuk memprediksi variasi variabel dependen (Ghozali, 2016).

2) Uji Statistik F

Uji $F$ adalah suatu uji yang dilakukan untuk menunjukkan bagaimana semua variabel independen yang dimasukkan dalam model mempengaruhi variabel dependen secara bersama-sama (Ghozali, 2016). Dalam penelitian ini menggunakan tingkat signifikansi sebesar $0,05(\alpha=$ $5 \%)$.

Adapun kriteria pengambilan penerimaan dan penolakan hipotesis yaitu :

a. Jika probabilitas signifikansi $\leq$ 0,05 maka variabel independen secara simultan atau secara bersama-sama berpengaruh tehadap variabel dependen.

b. Jika probabilitas signifikansi $\geq$ 0,05 maka variabel independen secara simultan atau secara bersama-sama tidak berpengaruh terhadap variabel terikat.

3) Uji Statistik t

Uji statistik t digunakan untuk menguji signifikansi koefisien variabel independendalam memprediksi variabel dependen. Pengujian ini pada dasarnya menunjukkan seberapa jauh pengaruh satu variabel penjelas atau independen secara individual dalam menerangkan variasi variabel dependen dengan asumsi variabel bebas lainnya bersifat konstan (Ghozali, 2016).

Dalam penelitian ini menggunakan tingkat signifikansi sebesar $0,05(\alpha=5 \%)$. Adapun kriteria pengambilan penerimaan dan penolakan hipotesis yaitu :

a. Jika signifikansi $\leq 0,05$ maka variabel independen (X) berpengaruh signifikan tehadap variabel dependen (Y).

b. Jika nilai koefisien regresi $(\beta)$ dan nilai t-hitung bernilai negatif maka menunjukkan bahwa variabel $\mathrm{X}$ memiliki arah yang berlawanan dengan variabel $\mathrm{Y}$ (berpengaruh negatif).

c. Jika nilai koefisien regresi $(\beta)$ dan t-hitung bernilai positif maka menunjukkan bahwa variabel $\mathrm{X}$ 
memiliki hubungan yang searah dengan variabel $\mathrm{Y}$ (berpengaruh positif).

Jika signifikansi > 0,05 maka variabel independen (X) tidak berpengaruh terhadap variabel dependen (Y).

\section{HASIL DAN PEMBAHASAN Analisis Statistik Deskriptif}

Statistik deskriptif memberikan gambaran atau deskripsi suatu data yang dilihat dari nilai ratarata (mean), standar deviasi, maksimum, dan minimum dari masing - masing variabel. Statistik deskriptif dimaksudkan untuk memberikan gambaran mengenai distribusi dan perilaku data sampel tersebut (Ghozali, 2016).

Berdasarkan hasil pengujian dengan statistik deskriptif disajikan dalam Tabel 4.1.

Tabel 4.1

Hasil Uji Statistik Deskriptif

\begin{tabular}{|l|l|l|l|l|l|}
\hline & $\mathrm{N}$ & Minim & Maxim & Mea & Std. \\
& & um & um & $\mathrm{n}$ & Deviati \\
VALUE & 54 & .15 & 82.44 & 8.40 & 15.481 \\
CSR & 54 & .05 & .25 & .149 & .04560 \\
IC & 54 & 1.49 & 11.09 & 4.04 & 2.4452 \\
DIV & 54 & .15 & .99 & .519 & .24890 \\
SOLV & 54 & .08 & 2.65 & .739 & .58257 \\
Valid N & & & & & \\
\hline
\end{tabular}

\section{Sumber : Data diolah (2019)}

Berdasarkan hasil analisis pada Tabel 4.1, maka dapat diketahui hasil bahwa :

1) Variabel Corporate Social Responsibility (CSR) memiliki nilai minimum 0,05 , nilai maksimum 0,25, deviasi standar 0,04560 dan nilai rata - rata sebesar 0,1496 .

2) Variabel Intellectual Capital (IC) memiliki nilai minimum 1,49 , nilai maksimum 11,09, deviasi standar 2,44525 dan nilai rata - rata sebesar 4,0472.

3) Variabel Kebijakan Dividen (Div) memiliki nilai minimum 0,15 , nilai Tabel 5.2 menunjukan bahwa hasil uji normalitas memiliki nilai Kolmogorov-Smirnov sebesar 0 ,
608 dan nilai signifikansi sebesar 0,854 lebih besar dari $\alpha=0,05$ artinya semua residual berdistribusi normal.

4) maksimum 0,99 , deviasi standar 0,24890 dan nilai rata - rata sebesar 0,5193 .

5) Variabel Rasio Solvabilitas (Solv) memiliki nilai minimum 0,08 , nilai maksimum 2,65, deviasi standar 0,58257 dan nilai rata - rata sebesar 0,7398 .

6) Variabel Nilai Perusahaan (Value) memiliki nilai minimum 0,15 , nilai maksimum 82,44, deviasi standar 15,48103 dan nilai rata - rata sebesar 8,4096. 


\section{Hasil Pengujian Asumsi Klasik \\ Uji Normalitas}

Uji normalitas dilakukan untuk menguji apakah model regresi, variabel penganggu dan residual berdistribusi normal atau tidak, karena data yang baik adalah data yang berdistribusi normal. Uji normalitas dapat dilakukan dengan metode Kolmogrov-Smirnov (Ghozali,2016). Data dapat dikatakan berdistribusi normal jika Asymp.Sig (2-tailed) lebih besar dari $\mathrm{a}=0,05$.

Hasil uji normalitas ditunjukan pada Tabel 4.2.

Tabel 4.2

Hasil Uji Normalitas

\section{One-Sample Kolmogorov-Smirnov Test}

\section{Sumber : Data diolah (2019)}

\begin{tabular}{|l|l|}
\hline & Unstandardized \\
\hline $\mathrm{N}$ & 54 \\
Kolmogorov- & .608 \\
Asymp. Sig. (2- & .854 \\
\hline
\end{tabular}

Tabel 4.2 menunjukan bahwa hasil uji normalitas memiliki nilai Kolmogorov-Smirnov sebesar 0, 608 dan nilai signifikansi sebesar 0,854 lebih besar dari $\alpha=0,05$ artinya semua residual berdistribusi normal.

\section{Uji Multikolinieritas}

Uji multikolineraritas bertujuan untuk menguji apakah pada model regresi ditemukan adanya korelasi antar variabel bebas (Ghozali, 2016). Untuk mendeteksi ada atau tidaknya korelasi antar sesama variabel bebas dapat dilihat dari nilai Variance Inflation Factor (VIF) dan tolerance. Jika nilai tolerance lebih besar dari 0,10 atau VIF kurang dari 10, maka dikatakan tidak ada gejala multikolinearitas. Hasil uji multikolinearitas ditunjukan pada Tabel 4.3

Tabel 4.3

Hasil Uji Multikolinearitas

Coefficients $^{\mathrm{a}}$

\begin{tabular}{|c|c|c|c|}
\hline & $\begin{array}{l}\text { Unstandardi } \\
\text { zed }\end{array}$ & \multicolumn{2}{|c|}{$\begin{array}{l}\text { Collinearity } \\
\text { Statictics }\end{array}$} \\
\hline Model & B & Tolera & VIF \\
\hline (Const & -14.788 & & \\
\hline CSR & -28.598 & .648 & 1.544 \\
\hline IC & 2.555 & .382 & 2.618 \\
\hline DIV & 12.097 & .580 & 1.724 \\
\hline SOLV & 14.674 & .615 & 1.627 \\
\hline
\end{tabular}

Sumber : Data diolah (2019) 


\begin{tabular}{ll}
\hline Tabel 4.3 menunjukan bahwa & 0,648, Intellectual Capital sebesar \\
nilai VIF semua variabel kurang dari & 0,382 , Kebijakan Dividen sebesar \\
10 dan nilai tolerance lebih besar dari & 0,580 , dan Rasio Solvabilitas sebesar \\
0,10. Corporate Social Responsibility & $0,615$. \\
memiliki nilai VIF sebesar 1,544, & Uji Autokorelasi \\
Intellectual Capital sebesar 2,618, & Uji autokorelasi bertujuan \\
Kebijakan Dividen sebesar 1,724, dan & apakah dalam model regresi terdapat \\
Rasio Solvabilitas sebesar 1,627. Hal & korelasi kesalahan penganggu pada \\
ini menunjukan bahwa dalam model & periode t dengan kesalahan penganggu \\
regresi tidak terjadi multikolinearitas. & pada periode t-1. Uji autokorelasi \\
Demikian juga dengan hasil uji & dalam penelitian ini dilakukan dengan \\
multikolinearitas menunjukan & pendekatan DW (Durbin -Watson). \\
variabel bebas yang memiliki & Hasil uji autokorelasi dapat dilihat \\
tolerance lebih dari 0,10 yaitu & pada Tabel 4.4. \\
Corporate Social Responsibility &
\end{tabular}

Tabel 4.4

Hasil Uji Autokorelasi

Model Summary ${ }^{b}$

\begin{tabular}{|l|l|}
\hline Model & Durbin-Watson \\
\hline 1 & 1.819 \\
\hline
\end{tabular}

\section{Sumber : Data diolah (2019)}

Berdasarkan Tabel $\quad 4.4$

menunjukan bahwa nilai Durbin Watson sebesar 1,819, dengan nilai du sebesar 1,7234. Hasil uji autokorelasi dengan metode Durbin-Watson berada diantara $\mathrm{du}=1,7234$ dan 4-du $=$ 2,2766. Oleh karena nilai DurbinWatson dari persamaan tersebut berada pada du $<\mathrm{d}<4$-du atau 1,7234 $<1,819<2,2766$ yang menunjukan bahwa data sampel penelitian ini tidak terjadi autokorelasi.

\section{Uji Heterokedastisitas}

Uji heterokedastisitas digunakan untuk menguji apakah dalam model terjadi ketidaksamaan varian dari residual satu pengamatan ke pengamatan yang lainnya (Ghozali, 2016). Jika tingkat signifikansi berada diatas 0,05 maka model regresi pada penelitian tidak terdapat heterokedastisitas. Hasil uji heterokedastisitas ditunjukan pada Tabel 4.5. 


\section{Tabel 4.5}

Hasil Uji Heterokedastisitas

Coefficients $^{\mathbf{a}}$

\begin{tabular}{|c|c|}
\hline Model & Sig. \\
\hline CSR & .974 \\
IC & .929 \\
DIV & .838 \\
SOLV & .312 \\
\hline
\end{tabular}

\section{Sumber : Data diolah (2019)}

Tabel 4.5 menunjukan bahwa nilai signifikansi masing - masing variabel independen pada penelitian ini lebih besar dari $\alpha=0,05$ yaitu Corporate Social Responsibility memiliki nilai sebesar 0,974, Intellectual Capital 0,929, Kebijakan Dividen sebesar 0,838, Rasio Solvabilitas sebesar 0,312. Maka disimpulkan bahwa tidak terjadi heterokedastisitas pada penelitian.

\section{Uji Analisis Regresi Berganda}

Model yang digunakan dalam penelitian ini yaitu pengaruh Corporate Social Responsibility, Intellectual Capital, Kebijakan Dividen dan Rasio Solvabilitas terhadap Nilai Perusahaan pada perusahaan sektor consumer goods yang terdaftar di Bursa Efek Indonesia Tahun 2016 - 2018 adalah analisis regresi bergada dengan bantuan program SPSS (Statistical Package Social Scienc) for windows versi 22.0 yang disajikan dalam Tabel 5.6 sebagai berikut :

Tabel 4.6

Hasil Uji Analisis Regresi Berganda Coefficients $^{\text {a }}$

\begin{tabular}{|c|c|c|c|c|c|}
\hline & $\begin{array}{l}\text { Unstandar } \\
\text { dized }\end{array}$ & \multicolumn{2}{|c|}{$\begin{array}{l}\text { Standardize } \\
\text { d }\end{array}$} & $\mathrm{t}$ & Sig \\
\hline Model & B & Std. & Bet & & \\
\hline (Con & -14. & 4.2 & & & .00 \\
\hline CSR & -28.598 & 28.79 & - & - & .32 \\
\hline $\mathrm{IC}$ & 2.555 & .699 & .40 & 3.65 & .00 \\
\hline DIV & 12.097 & 5.574 & .19 & 2.17 & .03 \\
\hline SOLV & 14.674 & 2.314 & .55 & 6.34 & .00 \\
\hline
\end{tabular}

\section{Sumber : Data diolah (2019)}

Berdasarkan Tabel 4.6 maka hasil uji t (uji parsial) adalah sebagai berikut :

1) Nilai signifikansi variabel Corporate Social Responsibility (CSR) sebesar 0,325 yang lebih besar dari $\alpha=0,05$ dengan nilai $\mathrm{t}$ 0,993, hal ini berarti Corporate Social Responsibility tidak berpengaruh terhadap Nilai Perusahaan dan dapat disimpulkan $\mathrm{H}_{1}$ ditolak. 
2) Nilai signifikansi variabel Intellectual Capital (IC) sebesar 0,001 yang lebih kecil dari $\alpha=$ 0,05 dengan nilai $t 3,653$, hal ini berarti Intellectual Capital berpengaruh positif terhadap Nilai Perusahaan dan dapat disimpulkan $\mathrm{H}_{2}$ diterima.

3) Nilai signifikansi variabel Kebijakan Dividen (Div) sebesar 0,035 yang lebih kecil dari $\alpha=$ 0,05 dengan nilai t 2,170, hal ini berarti Kebijakan Dividen berpengaruh positif terhadap Nilai Perusahaan dan dapat disimpulkan $\mathrm{H}_{3}$ diterima.

4) Nilai signifikansi variabel Rasio Solvabilitas $\left(\mathrm{X}_{4}\right)$ sebesar 0,000 yang lebih kecil dari $\alpha=0,05$ dengan nilai t 6,342 , hal ini berarti Rasio Solvabilitas berpengaruh positif terhadap Nilai Perusahaan dan dapat disimpulkan $\mathrm{H}_{4}$ ditolak.

\section{Uji Kelayakan Model}

Uji Koefisien Determinasi

Koefisien determinasi pada intinya mengukur seberapa jauh kemampuan model dalam menerangkan varian variabel dependen. Nilai koefisien determinasi adalah antara nol dan satu. Hasil uji koefisien determinasi ditunjukan pada Tabel 4.7.

Tabel 4.7

Hasil Uji Koefisien Determinasi $\left(\mathbf{R}^{\mathbf{2}}\right)$ Model Summary ${ }^{b}$

\begin{tabular}{|l|l|l|l|}
\hline Model & $\mathrm{R}$ & $\mathrm{R}$ & Adjusted \\
$\mathrm{C}$ & $\mathbf{\text { R }}$ & $\mathbf{\mathrm { n }}$ \\
\hline 1 & $.878^{\mathrm{a}}$ & .772 & .753 \\
\hline
\end{tabular}

\section{Sumber : Data diolah (2019)}

Berdasarkan Tabel 4.7 dapat diketahui bahwa nilai adjusted $\mathrm{R}^{2}$ sebesar 0,753 yang menunjukan bahwa 75,3 persen variabel terikat yaitu Nilai Perusahaan dapat dijelaskan oleh variabel Corporate Social Responsibility, Intellectual Capital, Kebijakan Dividen dan Rasio Solvabilitas. Sisanya sebesar 24,7 persen dijelaskan oleh variabel variabel lain yang tidak dimasukkan dalam model ini.

\section{Uji Signifikansi Simultan F}

Uji statistk $F$ pada dasarnya menunjukan apakah semua variabel independen dimasukan dalam model yang mempunyai pengaruh bersamasama terhadap variabel dependen
(Ghozali, 2016). Hasil uji F ditunjukan pada Tabel 4.8.

Tabel 4.8

Hasil Uji Signifikansi Simultan (Uji Statistik F)

ANOVA ${ }^{b}$

\begin{tabular}{|l|l|l|}
\hline Model & F & Sig \\
\hline $\begin{array}{l}\text { Regression } \\
\text { Residual } \\
\text { Total }\end{array}$ & 41.408 & $.000^{\mathrm{a}}$ \\
\hline
\end{tabular}

Sumber : Data diolah (2019)

Berdasarkan Tabel 4.8 menunjukan nilai $F_{\text {hitung yaitu }} 41,408$ dengan tingkat signifikansi 0,000 , lebih kecil dari taraf nyata yang 
ditetapkan sebesar 0,05. Hasil ini menunjukan bahwa model regresi tersebut dapat digunakan untuk memprediksi Nilai Perusahaan. Dapat disimpulkan bahwa variabel independen secara serempak berpengaruh pada variabel dependen.
Uji statistik t digunakan untuk menunjukan seberapa jauh pengaruh variabel independen secara individual terhadap variabel dependen. Uji statistik $t$ dalam penelitian ini digunakan untuk melakukan pengujian hipotesis. Hasil uji statistik $t$ dapat dilihat pada Tabel 4.9

\section{Uji Parsial (uji t)}

Tabel 5.9

Hasil Uji Signifikansi Parameter Individual

(Uji Statistik t)

Coefficients $^{\mathrm{a}}$

\begin{tabular}{|l|l|l|l|l|l|}
\hline & \multicolumn{2}{|l|}{$\begin{array}{l}\text { Unstandardi } \\
\text { zed }\end{array}$} & $\begin{array}{l}\text { Standard } \\
\text { ized }\end{array}$ & & \\
\cline { 1 - 4 } Model & B & Std. & Beta & $\mathrm{t}$ & Sig \\
\hline (Const & - & 4.22 & & - & .00 \\
CSR & - & 28.7 & -.084 & - & .32 \\
IC & 2.55 & .699 & .404 & 3.65 & .00 \\
DIV & 12.0 & 5.57 & .194 & 2.17 & .03 \\
SOLV & 14.6 & 2.31 & .552 & 6.34 & .00 \\
\hline
\end{tabular}

\section{Sumber : Data diolah (2019)}

Berdasarkan Tabel 5.9 maka hasil uji t (uji parsial) adalah sebagai berikut :

1) Nilai signifikansi variabel Corporate Social Responsibility (CSR) sebesar 0,325 yang lebih besar dari $\alpha=0,05$ dengan nilai $\mathrm{t}$ 0,993, hal ini berarti Corporate Social Responsibility tidak berpengaruh terhadap Nilai Perusahaan dan dapat disimpulkan $\mathrm{H}_{1}$ ditolak.

2) Nilai signifikansi variabel Intellectual Capital (IC) sebesar 0,001 yang lebih kecil dari $\alpha=$ 0,05 dengan nilai $t 3,653$, hal ini berarti Intellectual Capital berpengaruh positif terhadap Nilai Perusahaan dan dapat disimpulkan $\mathrm{H}_{2}$ diterima.

3) Nilai signifikansi variabel Kebijakan Dividen (Div) sebesar 0,035 yang lebih kecil dari $\alpha=$
0,05 dengan nilai t 2,170, hal ini berarti Kebijakan Dividen berpengaruh positif terhadap Nilai Perusahaan dan dapat disimpulkan $\mathrm{H}_{3}$ diterima.

4) Nilai signifikansi variabel Rasio Solvabilitas (Solv) sebesar 0,000 yang lebih kecil dari $\alpha=0,05$ dengan nilai t 6,342, hal ini berarti Rasio Solvabilitas berpengaruh positif terhadap Nilai Perusahaan dan dapat disimpulkan $\mathrm{H}_{4}$ ditolak.

\section{SIMPULAN DAN SARAN Simpulan}

Berdasarkan perumusan masalah dan hasil analisis yang telah diuraikan maka dapat disimpulkan pengaruh corporate social responsibility, intellectual capital, kebijakan dividen dan rasio solvabilitas terhadap nilai perusahaan pada perusahaan sektor consumer 
goods yang terdaftar di BEI periode tahun 2016 - 2018 adalah sebagai berikut :

1. Corporate social responsibility tidak berpengaruh terhadap nilai perusahaan pada perusahaan sektor consumer goods yang terdaftar di BEI. Hal tersebut disebabkan karena perusahaan tidak melakukan pengkomunikasian tanggung jawab sosial secara tepat sehingga belum ditangkap sebagai sesuatu yang perlu diperhatikan oleh pihak - pihak yang berkepentingan, sehingga investor cenderung lebih memperhatikan profit perusahaan dibandingkan pengungkapan $C S R$ yang dilakukan perusahaan.

2. Intellectual capital berpengaruh positif terhadap nilai perusahaan. Hal ini disebabkan karena perusahaan mampu mengoptimalkan pemanfaatan sumber daya atau potensi yang dimiliki sehingga akan menciptakan keunggulan kompetitif bagi perusahaan. Para investor akan lebih menghargai perusahaan yang memiliki $I C$ yang unggul dan berinvestasi pada perusahaan tersebut, sehingga akan berdampak pada naiknya nilai perusahaan.

3. Kebijakan dividen berpengaruh positif terhadap nilai perusahaan. Hal ini disebabkan karena investor dalam berinvestasi selalu mengharapkan return dari investasi yang dilakukan. Oleh karena itu, perusahaan yang membagikan dividen akan menarik minat investor untuk berinvestasi dan kemudian akan meningkatkan nilai perusahaan tersebut.
4. Rasio solvabilitas berpengaruh positif terhadap nilai perusahaan. Hal ini disebabkan karena perusahaan yang menggunakan hutangnya secara efektif dan efisien diyakini dapat meningkatkan laba perusahaan. Perusahaan menggunakan modalnya untuk ekspansi atau pengembangan bisnis, sehingga investor tertarik untuk membeli saham perusahaan tersebut dan kemudian akan berdampak pada meningkatnya nilai perusahaan.

\section{Saran}

Adapun saran yang diberikan untuk peneliti selanjutnya adalah sebagai berikut :

1. Dalam penelitian ini hanya menggunakan perusahaan sektor consumer goods yang terdaftar di BEI sebagai sampel. Penelitian selanjutnya diharapkan untuk melakukan penelitian diluar sektor consumer goods yaitu seperti sektor perbankan, pertambangan, property dan real estate, transportrasi.

2. Dalam penelitian ini hanya menunjukan bahwa 75,3 persen variabel terikat yaitu Nilai Perusahaan dapat dijelaskan oleh variabel Corporate Social Responsibility, Intellectual Capital, Kebijakan Dividen dan Rasio Solvabilitas sedangkan sisanya sebesar 24,7 persen dijelaskan oleh variabel-variabel lain yang tidak dimasukkan dalam model ini. Penelitian selanjutnya diharapkan dapat menggunakan variabel lain yang tidak terdapat 
dalam model penelitian ini seperti pertumbuhan perusahaan, leverage, kepemilikan saham, good corporate governance dan variabel lainnya yang nantinya diharapkan dapat berpengaruh terhadap nilai perusahaan.

3. Dalam penelitian ini hanya menggunakan 3 (tiga) periode. Penelitian selanjutnya hendaknya dapat menambah periode pengamatan yang lebih panjang.

\section{DAFTAR PUSTAKA}

Ahmed, A .2016. Impact of Intellectual Capital on Firm Value: The Moderating Role of Managerial Ownership. Journal of Sosial and Sciences Vol 1 No.3 (2016).

Aprianti, Siska. 2018. Pengaruh VACA, VAHU dan STVA terhadap Nilai Perusahaan (Studi pada Perusahaan Perbankan yang terdaftar di BEI periode 2011-2014). Jurnal Riset Terapan Akuntansi Vol. 2 No. 1 (2018).

Arindita, Galuh. 2015. Analisis Pengaruh Struktur Modal, Profitabilitas, Kebijakan Dividen, dan Size Terhadap Nilai Perusahaan (Studi Empiris pada Perusahaan Wholesale dan Retail yang terdaftar di BEI tahun 20082012). Skripsi. Fakultas Ekonomi dan Bisnis Universitas Diponegoro.

Arifah, D. 2015. Keputusan Investasi, Keputusan Pendanaan dan Kebijakan Dividen terhadap Nilai Perusahaan Manufaktur yang terdaftar di BEI tahun 2008-2010. Naskah Publikasi Universitas Negeri Sumatera Utara.

Azis, R.Y. 2017. Pengaruh Keputusan Investasi, Kebijakan Dividen, dan Kebijakan Hutang terhadap Nilai Perusahaan (Studi Empiris pada Perusahaan Manufaktur yang terdaftar di BEI tahun 20132015). Skripsi. Fakultas Ekonomi Universitas Negeri Yogyakarta.

Brigham, E. F dan J. F Houston. 2014. Manajemen Keuangan. Edisi Bahasa Indonesia. Jakarta: Erlangga.

Fauzia, N., dan Amanah, L. 2016. Pengaruh Intellectual Capital, Karakteristik Perusahaan, dan Corporate Social Responsibility terhadap Nilai Perusahaan. Jurnal Ilmu Dan Riset Akuntansi Vol.5 No.4 (2016) h:1-22.

Ghozali, Imam. 2016. "Aplikasi Analisis Multivariate dengan Program IBM SPSS 23 ". Semarang: Undip.

Hadiwijaya, Rendi Cahyo. 2013. Pengaruh Intellectual Capital terhadap Nilai Perusahaan dengan Kinerja Keuangan sebagai variabel intervening. Skripsi. Fakultas Ekonomika dan Bisnis Universitas Diponegoro.

Halim, Abdul. 2015. "Auditing (Dasar-dasar Audit Laporan Keuangan)".'Yogyakarta: Unit 


$\begin{array}{lllr}\text { Penerbit dan } & \text { Percetakan } & \text { Fakultas } & \text { Ekonomika dan } \\ \text { STIM. } & & \text { Bisnis } & \text { Universitas } \\ & & \text { Diponegoro. }\end{array}$

Hapsak, H.W.P. 2018. Analisis Likuiditas, Solvabilitas dan Rentabilitas terhadap Nilai Perusahaan (Studi Empiris pada Perusahaan Food and Beverage yang terdaftar di BEI periode 2014-2017). Naskah Publikasi Universitas Muhammadiyah, Surakarta.

Harmono, 2014. Manajemen Keuangan Berbasis Balance Scorecard. Teori Kasus dan Riset Bisnis. Jakarta: Bumi Aksara.

Hartoyo. 2016. Pengaruh Kebijakan Dividen terhadap Nilai Perusahaan (Studi Kasus pada Perusahaan Perbankan yang Terdaftar di Bursa Efek Indonesia Periode Tahun 2010-2013). Naskah Publikasi Universitas Muhammadiyah, Surakarta.

Jitmanerooj, Boonlert. 2017 . The impact of Corporate Social Responsibility on Firm Value: an application of structural equation modelling. International Journal of Business Governance and Ethics Vol.12 No. 4 (2017).

Khafa, Lais. 2015. Pengaruh Corporate Social Responsibility, Ukuran Perusahaan, Leverage, dan Keputusan Investasi Terhadap Nilai Perusahaan (Studi Empiris pada Perusahaan Manufaktur yang terdaftar di BEI tahun 2012-2013). Skripsi

Lutfiana, Azizah. 2018. Pengaruh Solvabilitas, Profitabilitas dan Likuiditas terhadap Nilai Perusahaan (Studi Empiris pada Perusahaan Properti dan Real Estate yang terdaftar di BEI periode 2014-2017). Skripsi. Fakultas Ekonomi Universitas Yogyakarta.

Noviyani, I. 2018. Pengaruh Profitabilitas dan Solvabilitas terhadap Nilai Perusahaan dengan Corporate Social Responsibility sebagai variabel moderasi (Studi Empiris pada Perusahaan Sektor Pertambangan yang terdaftar di BEI 2012-2016). Skripsi. Fakultas Ekonomi dan Bisnis Universitas Pasundan Bandung.

Nurfina, H.E. 2016. Pengaruh Corporate Social Responsibility, Kebijakan Deviden, Profitabilitas, Struktur Modal dan Ukuran Perusahaan terhadap Nilai Perusahaan (Studi Empiris pada Perusahaan Manufaktur yang Terdaftar di BEI periode 2010 - 2014). Skripsi Fakultas Ekonomi dan Bisnis Universitas Diponegoro, Semarang.

Nuryaman. 2015. Pengaruh Intellectual Capital terhadap Nilai Perusahaan dengan Kinerja Keuangan sebagai variabel intervening (Studi 
Journal of Applied Management and Accounting Science (JAMAS)

(Ni Luh Tiya Arini, Ni Nyoman Ayu Suryandari, A.A. Putu Gde Bagus Arie Susandya, 38 - 55) Vol 1, No 1, Desember 2019

Kasus pada Perusahaan Manufaktur yang terdaftar di BEI tahun 2010-2011). Jurnal Ekonomi dan Bisnis Vol. 211 No.1 (2015).

Rofik, A. 2017. Analisis Pengaruh Struktur Modal, Profitabilitas, dan Intellectual Capital terhadap Nilai Perusahaan (Studi Empiris pada Perusahaan Property dan Real Estate yang terdaftar di ISSI tahun 2014-2016). Skripsi Fakultas Ekonomika dan Bisnis Universitas Muhammadiyah Surakarta.

Sartono, Agus. 2014. "Manajemen Keuangan: Teori dan Aplikasi”. Yogyakarta: BPFE.

Setianingrum, Wahyuning Ambar. 2015. Pengaruh Corporate Social Responsibility terhadap Nilai Perusahaan dengan Profitabilitas sebagai variabel moderasi (Studi Empiris pada Perusahaan Manufaktur yang terdaftar di BEI periode 20112013). Skripsi. Fakultas Ekonomi Universitas Negeri Semarang.

Setyowati, T. 2014. Pengaruh Profitabilitas, Kebijakan Dividen,dan Corporate Social Responsibility terhadap Nilai Perusahaan (Studi Empiris pada Perusahaan Manufaktur yang Listing di BEI tahun 2009 -2012). Naskah Publikasi. Universitas Muhammadiyah Surakarta.
Sugiyono. 2013. "Metodologi Penelitian Bisnis". Bandung: Alfabeta.

Suparno, 2017. Pengaruh Intellectual Capital dan Earning Per Share terhadap Nilai Perusahaan (Studi Empiris pada Perusahaan LQ45 yang terdaftar di BEI tahun 20102014). Jurnal Manajemen dan Keuangan Vol.6 No.1 (2017).

www.idx.co.id 